\title{
The Influence of Personal Religiosity Level against Corruption Behaviour in the Province of Bangka Belitung Islands
}

\author{
Muhadam Labolo \\ Faculty of Government Politic, Institut Pemerintahan Dalam Negeri
}

Alma'arif*

Faculty of Government Management, Institut Pemerintahan Dalam Negeri

Muhammad Riqqo Khadafi

Faculty of Government Management, Institut Pemerintahan Dalam Negeri

Received: April 8, 2018 Accepted: June 6, 2018 Online published: June 11, 2018

doi:10.5296/jpag.v8i2.12977ＵRL: https://doi.org/10.5296/jpag.v8i2.12977

\begin{abstract}
The purpose of current study was to analyze the relationship between religion and ccorruption behavior. Corruption was a major problem that constantly being a disease to the third world country, included Indonesia. The magnitude of problems made the Government of Indonesia kept pressing the of corruption case consciously that already existed. Indonesia's corruption index in last few years continued to undergo the improvements though there have no significant changes. Through a theory stated religion could bring a positive implication for corruption behavior and also brought a negative impact on the corruption behavior of a person. The influence of personal religiosity level in the subsequent discussion was used a quantitative-explorative approach integrated with the qualitative-descriptive approach (mixed approach). The study was conducted in Bangka Belitung Islands Province aimed to find out and analyzed the issues. The results of processed data showed that people in Province of Bangka Belitung Islands have a high level of personal religiosity. Other findings showed that the influence of religion is important in reducing the level of corruption in the middle of the community. In the other hand, the society noted a giving of gifts to apparatus of government was a reasonable thing with a couple of notes. The result of the analysis showed the personal religiosity level in religion was still formed as ritualistic. Values and norms existed in
\end{abstract}


society are generally influenced by the ethics and culture in an area, religious piety still not in touch with the daily attitude and behavior of a person. Furthermore, it was also making some of society became tolerant of the law or rules.

Keywords: corruption, personal religiosity, attitude and behavior, ethics in area

\section{Introduction}

Corruption is a symptom which still and continue to undermine the nation's problems. Corruption in the economic sector is particularly slow the economic growth and investment, poor the quality of good and service, decline the productivity and decrease the state income also increase the domestic debt. On the social side, it causes the amount of violence, slows the poverty alleviation, creates the expensiveness of goods and public services and also decreases the quality of life. The impact to the government is collapsing the authority, capability, and integrity through public and private perspective, weakening the social and political ethics of the nation, strengthening the absolute of political system and/or governmental system dominated by financiers, also causing the function and task of government will not running well (bad governance). The negative impression received by nation makes government strived to uphold the eradication and prevention of corruption in every sector.

Corruption Perception Index (CPI) 2017 shows a raising level to corruption perception in Indonesia. A survey conducted in 12 major cities in Indonesia has yielded a mean score of 60.8 where an index of 0 means as the most corrupted and 100 as the cleanest. A corruption perceptions index is measuring the perceptions of corruption made by the businessmen and experts against the practice of bribery in an area. In 2017 the CPI of Indonesia has increased in score 6.1 compared to the score in 2015 with an average score of 54.7.

In the perspective of religion and beliefs, every religion teaches its believers to not harm others. None of the religions justifying corruption practices in daily life. Islam as the majority religion in Indonesia consisted by 207 million believers or approximately $87 \%$ of the total population is strongly denounce the corruption behavior. The status quo is showing the reality of Muslim' development has a major impact on the development of a country and nation, the achieved progress done by Muslims is properly in line with the situation in Indonesia. On the contrary, the decadence of Muslim is seen as great rift to deterioration of state.

In a survey conducted by Pewforum in 2012, Muslims of Indonesia constituted one of the most loyal adherents in the world. This survey showing Muslims in Indonesia is very obedient in carrying the five pillars of Islam such creed, prayer, fasting, tithe, and pilgrimage. Approximately 93\% of Muslims in Indonesia see religion as one of the most important things in spending the daily routine. While the loyalty in Ramadhan fasting in the Southeast Asian region showed a percentage of $99 \%$ and almost $93 \%$ of Muslims in Southeast Asia claimed to pay tithe every year. The fact is exceeding the Arabian Countries (Middle East-North Africa) where it only consisted of $89 \%$ Muslims in doing so.

Normatively, religion should be able to control the corruption behavior. The fact shows that nations with the majority of the religious population are not fully free from corruption 
practices. A corruption case in the fourth stage found in some country with a strong religious identity (Corruption Perception Index, 2011). A survey explaining Muslim in Indonesia said that every Muslim in Indonesia as one of the most loyal adherents in the world but the survey has not significantly impacted in declining the number of corruption. Indonesia always has a high score of corruption. For example, in the last 6 month from $1^{\text {st }}$ of January until $30^{\text {th }}$ of June 2017, Indonesia Corruption Watch (ICW) noted 226 cases of corruption. The suspect consisted of 587 people then it worths 1.83 trillion with bribery practice reaching 118.1 billion. Moreover, in 2016, Indonesia Corruption Watch (ICW) found the amount of corruption case reached 482 cases, suspected 1.101 people and state loses reached 1.45 trillion. This is not included corruption in village budgeting case with 110 cases in the current period 2016-2017.

The purpose of this study is to analyze and find out the influence of personal religiosity against the corruption behavior. This issue is very unique and interesting to be examined since it is useful to understand the influence of rate of religiosity level to against corruption behavior also contribute to the development of social science research and can be used as an additional material and information to a learned science. The practical benefits of this study are intended as an input of material and source of information and improve or overcome the weakness that may occur and also as a source of information in solving the urgent of corruption issues in Indonesia.

Based on data and some of the study cases, the author made an initial hypothesis illustrating a religion as something which is important for people in Indonesia and it included people in Bangka Belitung Island. For example, in 2016, it was 31 criminal cases of corruption dealt by High State Prosecutor and Prosecution. During 2017, It has 8 corruption cases dealt with Subunit of Tipikor Ditkrimsus in Bangka Belitung Island. In the range of 3 years, from 2013 to $\mathrm{f} 2015$, there were 142 complaints of alleged criminal acts of corruption to the Commission of Corruption Eradication (KPK). Thus, the number of criminal acts such corruption in the province of Bangka Belitung Island is still quite low or even very small as compared to other provinces. However, the retrieved data has grouped the corruption case as a large-scale issue and it can't be stated as the perception of people in Bangka Belitung Island to the corruption behavior in general, wide and sharp perspective.

In the end, the correlation between obedience and personal religiosity of a person viewed as a double-edged side, on one side it brings positive implications and on another hand, it brings a negative impact depending on the value and understanding of people. The tendency in understanding religion in depth and extensive view, not partial and don't see religion in narrow perspective lead to the importance of honesty, accountability, professionalism, transparency, equality, integrity and others as it will push the corrupt behavior of a person. Otherwise, a partial understanding of religion and a tendency to see religion as ritualistic will not bring a positive implication to the world issues like corruption acts. Similar things also expressed by some scholars who found religion as a contributing factor to positive, negative, or even not associated to corruption act (Ghaniy \& Hastiadi, 2017; Shabbir \& Anwar, 2007). One thing that should be agreed is a fact about religion doesn't increase a person's corruption behavior (Shadabi, 2013). 
Therefore, the authors interested in answering a number of questions about the relationship between corruption to religion, whether religious piety of a person affects behavior and attitude toward corruption, also why the considerable factor has a big influence to corruption behavior to religious people.

\section{Literature Review}

Oxford student's dictionary (in Azra, 2000) defined religion as a belief in the existence of a power in a supernatural force that creates and controls the universe. Michel Meyer (in Rousydiy, 1986) argued religion as a set of beliefs and teaching in directing people in its behavior to Allah, human being and himself. Nasution (1986) stated religion has a meaning as bond held and observed by humans. The intended bonds come from one of a higher power from man as supernatural powers that cannot be captured by the five senses, but it has a huge power in influencing human living cycle. According to Uyun (1998), a religion encouraged believers doing goods and responsible for every acts as well as effort in self-improving in order to be better.

Every scholar of social science does not see religion through normative and formal perspective because the method can't explain the behavior of corruption. They rather see values, norms, and behaviors are related directly to the practice of corruption. For example, norms and rules about accountability, professionalism, equality, and loyalty against the law that associated with democratic values (Seldadyo \& De Haan, 2006; Serra, 2006). In this context, values, norms, and culture in religion can't be viewed in rigid form, but there is another understanding developed by the religious community.

According to Jalaluddin (2004), religion has several functions in human living, i.e. as follows: educative function, religious tenet teaches some of the observed gospel. In this case, it instructs and prohibits in order to maintain every adherent to be good and accustomed to the good one. Rescue function, salvation is given by religion to every adherent is a safety including two worlds namely world as people live today and the hereafter. Peace function, through religion, someone who is guilty or sinful can achieve inner peace through religious guidance. Social supervision function, every adherent considered religion as a norm, so in this case religion served as social supervision in individual and group. Cultivating a sense of solidarity function, every adherent of one religion has the same psychologically feeling in the unity of faith. A sense of unity is fostering the sense of brotherhood. Transformative function, religious tenet can change someone's personality of individual or group into a new value of life in accordance with the religious tenet adhered by the stakeholder, sometimes the new value of life able to change someone's loyalty to the previously embraced norm. Creative functions, religious tenets encouraged and invited its followers to work productively not only for their own interest but also others interest. Adherents of religions not only ordered to work regularly in the same life patterns, but also required to invent an innovation and new discoveries. Sublimative function, religious tenet tends to sanctified every human effort, not only to the religious nature of ukhrawi but also religious nature of world values.

Transparency International using a definition of corruption as: "the misuse of power and 
public trust for personal interest" (Pope, 2003:6). Some understanding of corruption according to John A. Gardiner and David J. Olson, quoted by Martiman Prodjohamidjojo (2001:8-12) such: (1) The formulation of corruption from the perspective of marketing theory, Jacob Van Klaveren said that a corrupting servants of state (civil servants) assuming the institution/office as trading company, so his work as a servant focused on keeping a high revenue. (2) The formulation focused on the position in the governmental system, M. Mc. Mullan stated that the officers of government who doing corruption is when he received money to do a work that should not be belonged as his position responsibility whereas he is not allowed to do it as he runs his job. J.S. Nye argued corruption as a strayed behavior from the normal obligation of a governmental institution role, caused by individual interest (family, groups, friends) to pursue a social status and prestige or break the rule through doing or finding influence for individual interest. (3) The formulation of corruption focused on public interest, Carl J. Friedrich, stated a pattern of corruption exists as if someone holds an authorized power to do certain things like an official who is responsible through unpermitted money and another gift in the constitution; coaxing in taking a step that help whoever providing gifts thus completely harms the public interest. (4) Formulation of corruption based on sociology view, the sociological meaning of corruption studied by Martiman Prodjohamiodjojo stating the opinion of Sheikh Hussein Alatas that said corruption occurs if a public servant receives a present given by someone in case of attracting him to give special attention of the giver interest. Sometimes it also an action offering a granted money as prizes to other as it tempting the servant. In this definition, it included an exploitation like a demand, giving or gift in the implementation of public tasks managed by their own interest.

\section{Methodology}

This study aimed to analyze the influence of religiosity level toward the corruption behavior. The initial method used in analyzing this issue through implementing quantitative-explorative method followed by the qualitative-descriptive method. Therefore, the analysis will be done in analyzing the correlation between personal religiosity to the corruption behavior in daily life then it followed by analyzing others factor influencing the corruption behavior. Study activities started by determining the hypothesis of study as the validity has been tested. Furthermore, the study continued in analyzing the validity and reliability of every question in the questionnaire distributed directly. The question form provided in a questionnaire form with closed type.

The dual regression analysis (multiple regression) is used in proving the validity of the submitted hypothesis. Through analysis result, it showing the influence of religion in suppressing corruption behavior among people. The study was done to Islam adherent in Province of Bangka Belitung Island which occurred during a period of December of 2017 until January of 2018. It used SPPS software to process the data. The further stage was analyzing the collecting data by doing re-check, check, and cross-check against the data with specific sampling correspondent. In this study, it arranged a model providing a whole picture of the examined object. 


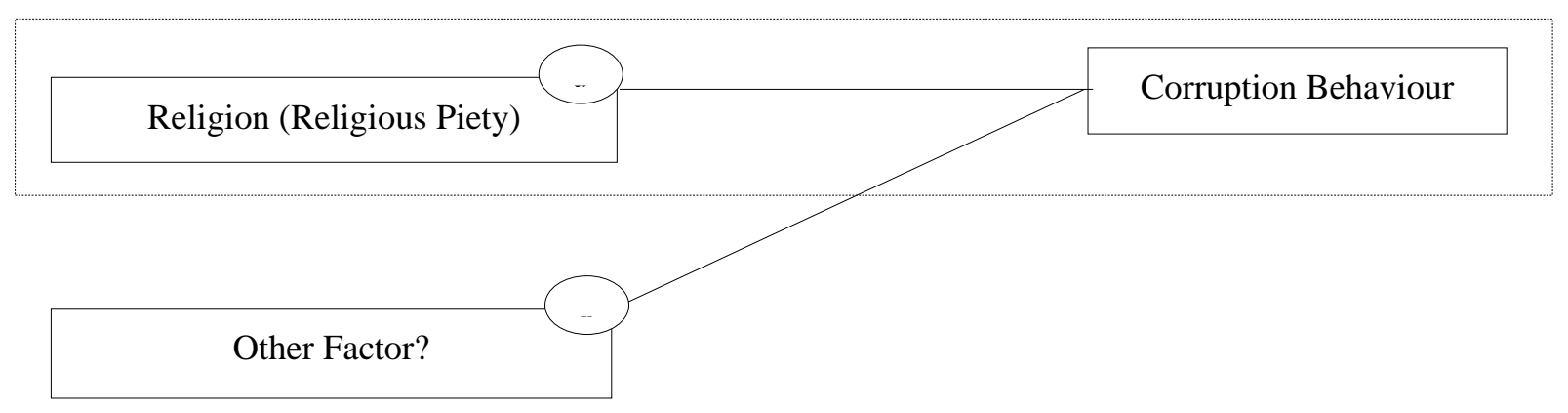

Independent Variable $(\mathrm{X})$

Dependent Variable (Y)

After analyzing the relationship between religion (the focused analysis on religious piety) to corruption behavior followed by determining the other factors which affected to the corruption behavior of a person. The determination of the other factors is done through interview techniques and observations in some cases. The population used in the interview process is consisted by the person revealing himself virtuously loyal in exercising religion value. The number of informants who conducted an interview done to 10 people which are selected randomly.

\section{Result and Discussion}

As the questionnaire has formed, it distributed to 200 respondents directly. It uses a Likert scale and all respondents are being asked to choose an answer that consisted of number 1 (strongly disagree) to number 5 (strongly agree) in the proposed questionnaire. Furthermore, after being accumulated, 200 questionnaires will be tested its validity and reliability. Several characteristics are represented by a number of valid and reliable question. It caused by the analysis result that showing from five characteristics has been qualified, as the corrected item-total correlation $\geq 0.3$ and the value of alpha Cronbach's $(\alpha) \geq 0.7$. Hence, each question in the questionnaire is valid and reliable.

Demographics of respondents consists of 97 male respondents 103 woman respondents. Based on the occupation carried by each respondent, it showed that 24 respondents are students, 63 respondents are self-employed, 87 respondents are farmers and 26 others respondents came from a different background of work. The entire of respondents aged 20-40 years. 


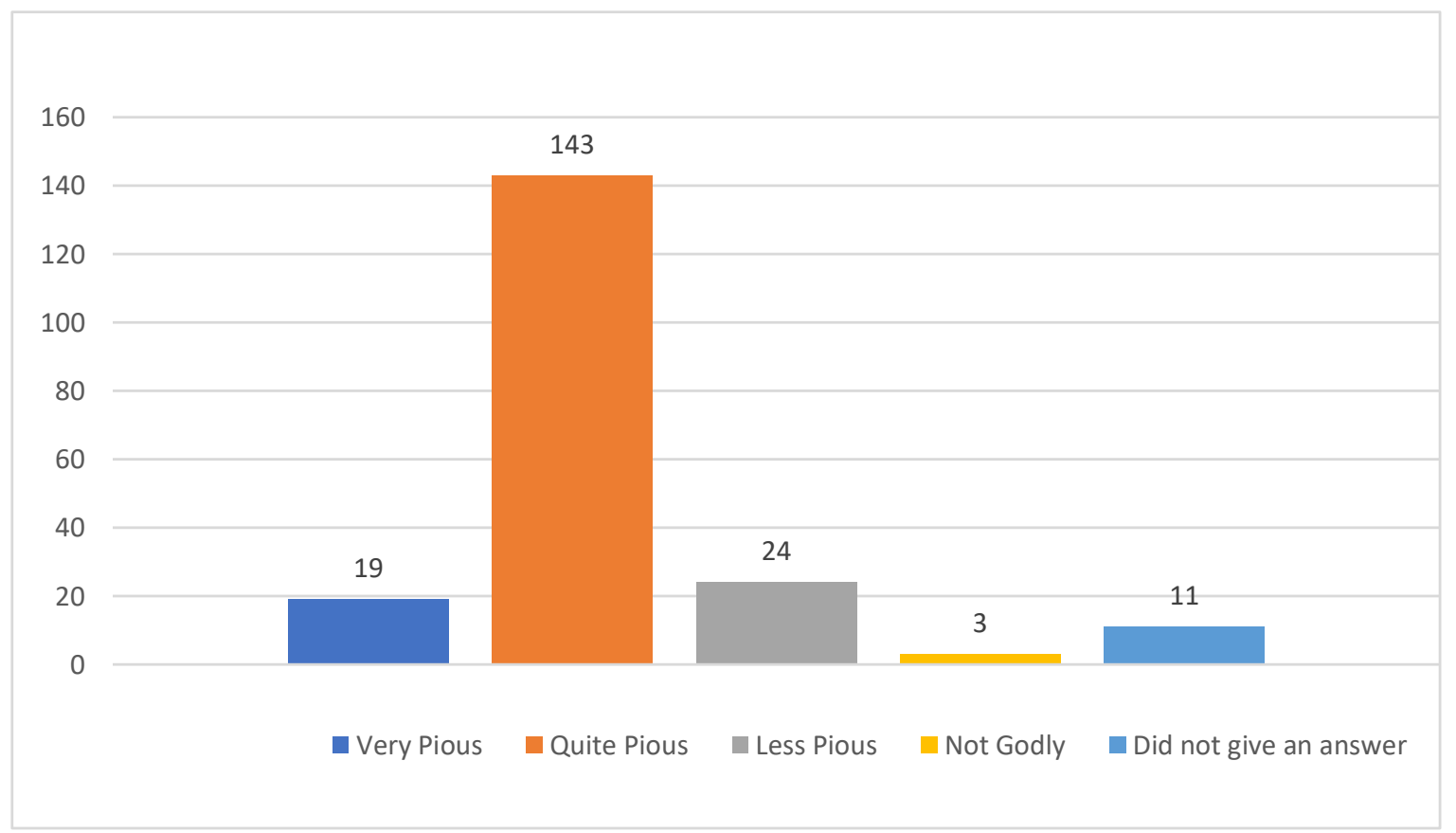

Source: Processed by the authors

Figure 1. Piety Level of Muslim Community

The result of processed data indicating that 162 people declared himself as very/quite devout enough in the running daily worship. From the 162 respondents who declared himself very/quite devout, the authors re-grouping with five levels of questions. The fifth question is explained as in figure 2.

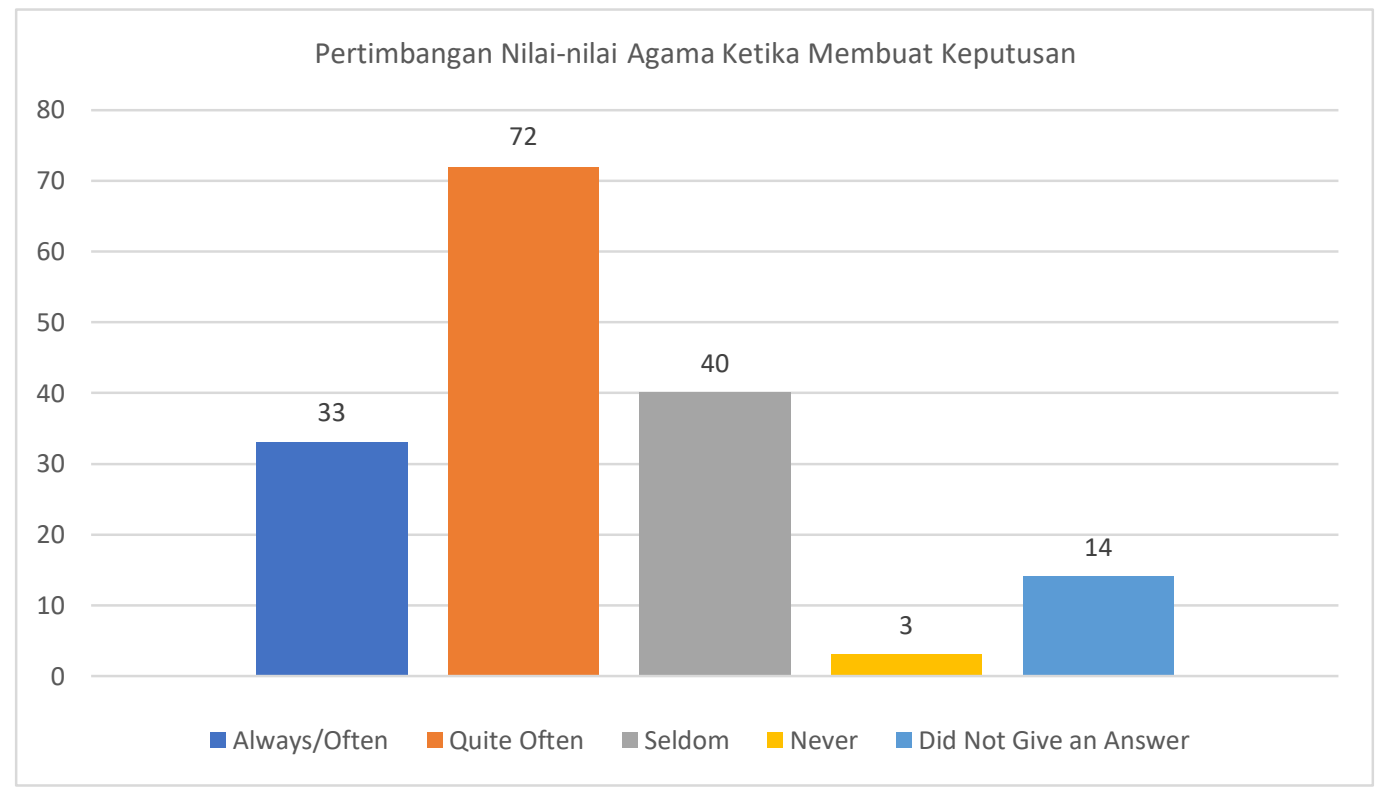

Source: Processed by the authors

Figure 2. Considerations of Religious Values in Policy Making 


\section{Macrothink}

Journal of Public Administration and Governance

ISSN 2161-7104

2018, Vol. 8, No. 2

From the data above, there are 33 respondents declaring himself always/very often considering the religious value when making a decision in life and 72 respondents declaring often enough. Thus, there are 105 respondents who consider religion in making a decision every single day. From 105 respondents, authors re-grouping their attitude toward gratification. The respond is presented in figure 3.

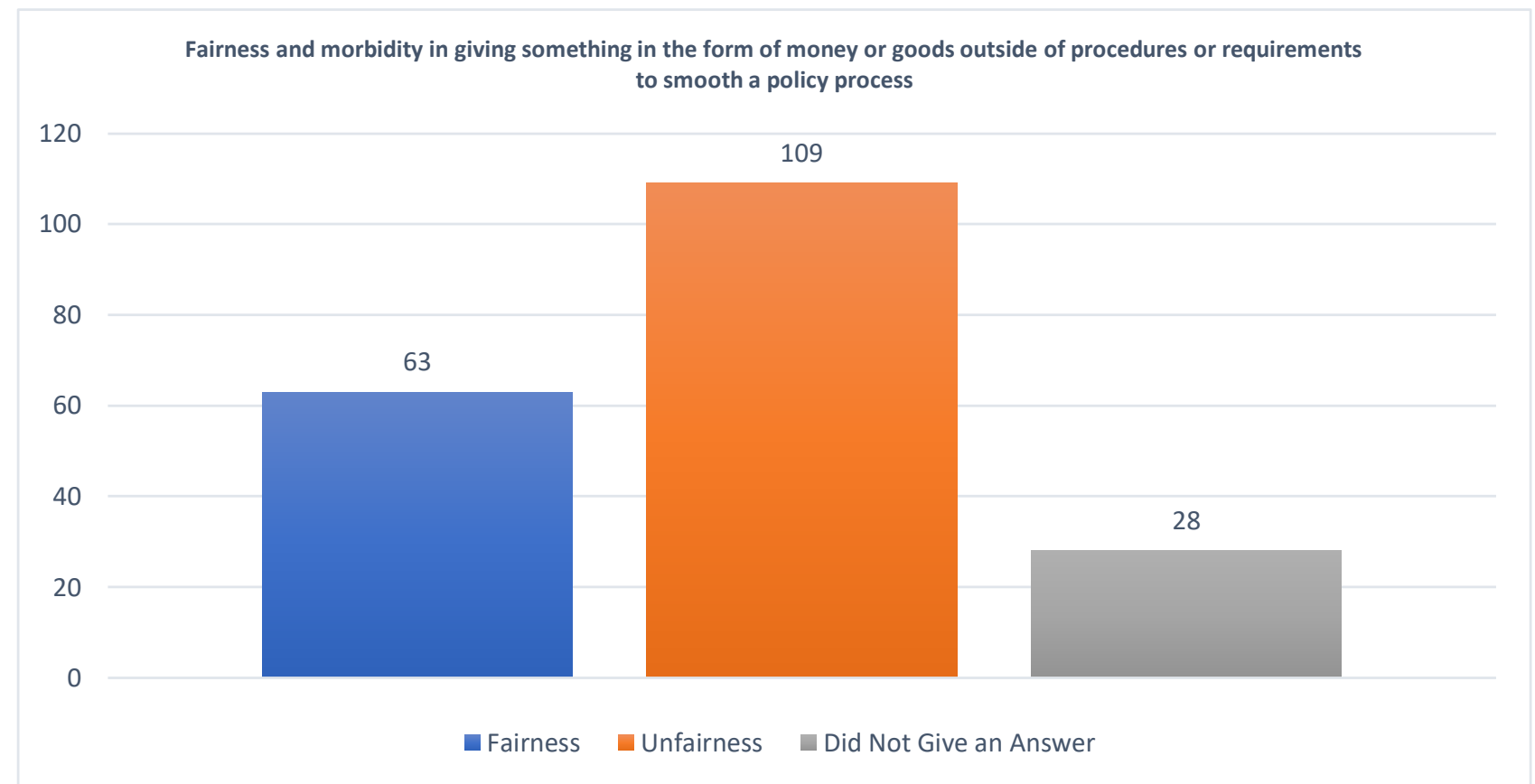

Source: Processed by the authors

Figure 3. Attitudes Towards Gratuities

The result of the processed data (questionnaire) shows the majority of society consisted by 64 respondents, $(60.9 \%)$ who mentioning the given gift outside the procedure and requirements in accelerating some process or the gratitude form in dealing with governmental agencies is unreasonable. Whereas the contrast results showed by 33 respondents $(31.4 \%)$, they state given a gift as something reasonable to do. 


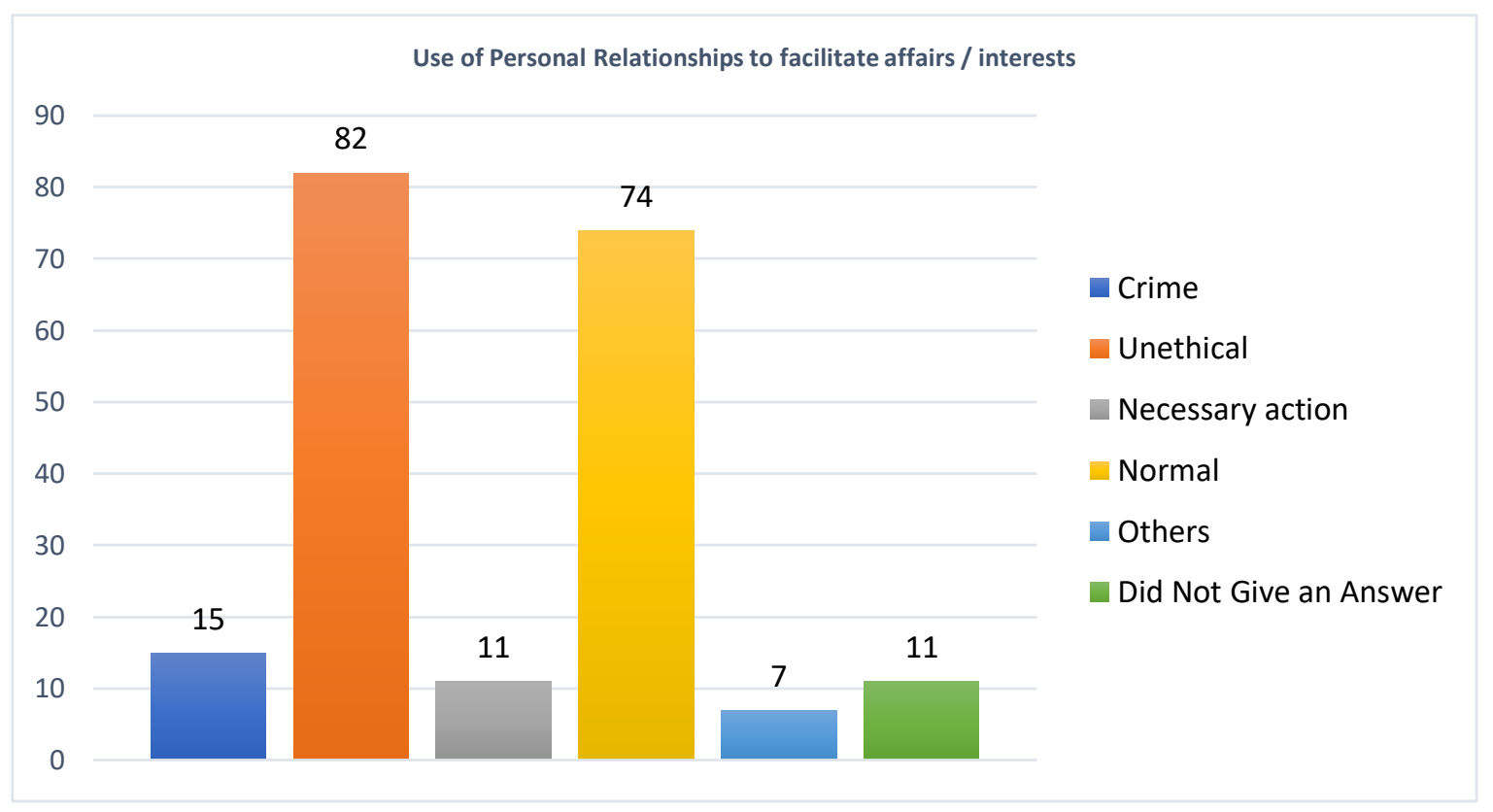

Source: Processed by the authors

Figure 4. Opinion About Collusion and Nepotism

Processed data is indicating the majority of society argued about collusion and nepotism as a negative action with a probability of 45 respondents judge it as unethical (42.8\%) and 11 respondents judge it as a crime and criminality $(10.4 \%)$. Nonetheless, there is a thing to be noted that 7 respondents judge it as something which is necessary and reasonable to accelerate some processes $(6.6 \%)$ and 37 respondents see it as a normal and reasonable thing (35.2\%). In other words, there is $41.8 \%$ respondent considering the use of personal relations (through acquaintances or family) to accelerate the handling process of an interest is allowed and reasonable.

Further research indicates that there are other factors affecting the characteristics and behavior of a person as it included corruption behavior. The interview conducted with 10 informants taken randomly from 163 respondents who declared himself very/quite devout mentioning some factors that affect the perspective and behavior against corruption, such as:

\section{Ethics}

Ethics understood and defined as: "values and moral norms handled by a person or group of people in regulating his behavior and it also can be defined as a set of fundamental or moral values" (Bertens, 1993:6). On another side, culture is defined as a belief and behavior that arranged or taught from man to the next generation (Taylor, 1989). Goodenough (Kalangie, 1994) suggested that culture is a cognitive system consisted of knowledge, beliefs, and values of member' thought of society. Thus ethics and culture formed attitudes, behavior and social structures that exist inside society as it also occurs inside Bangka Belitung Island society. Results of interviews indicating the ethics and culture embedded inside the culture of the society in Bangka Belitung has quite dominant influence in determining the attitude and 
behavior against corruption. The same result also has been obtained from the collected data through observation techniques. The example of similar case in field showing that the existence of culture inside society to serve and entertain the guest who came to a house, there is a sense like "dak name" (read: hesitating feeling) of a person if he is not doing well against the guest and there is a reciprocal basic held by society' living cycle. Another case like an institution providing a relief to a group of people where the process of granting either socialization or awarding grant (deconcentrating funding or others) is becoming compulsory inside the culture of society even if he could only serve a cup of coffee (in some cases, a prize like agricultural product also means as prevalent thing). On the other hand, an official of government who is in charge to conduct socialization or provide funding/assistance need to accept the banquet as appreciation form to house owner as he has serviced the guest with his fullest dedication.

Psychologically, the values are kept exciting inside the culture of society, however, it also can't be categorized as something relatively bad/negative. There is a harmony shaped as a tradition that respects every fellow of official apparatus to society. This statement is in line with the condition of villagers tendency on gemeinschaft instead of Gesellschaft. The limitation describes the characteristic of an existing village in Bangka and Belitung as expressed by Ferdinand Tonies inside his writing Gemeinschaft und Gesellschaft. However, this situation created negative excess to society if there is one of society who not capable of serving the guest (apparatus official). Thus, banquets will become a competition and rivalry in keeping the help of government since governmental apparatus serving an assistance for people who proposed the best banquets. Initially, this value existed as an ethic value that developed into gratuities then created collusion behavior within its development.

\section{Worship As Ritualistic}

The assumption of society is quite dominant in declaring worship as a ritualistic form between the servant into his Lord. It is obtained from the result of interviews conducted against 10 informants who declared himself very or quite pious. The results stated that 9 out of 10 informants use his worship as the indicator in determining their statement while 1 informants explaining a different thing. Therefore, the indicator in declaring whether someone very or quite pious is through five fundamental pillars of Islam like creed, prayer, fasting, tithe, and pilgrimage to those who are able to afford it. Statement from all informants is not entirely wrong or true since there is another factor that matters in asserting someone as very or quite piety like an attitude and behavior to its society known as hablumminannas.

The dichotomy of thought declaring worship as the whole form of ritualistic makes someone perception about lesson and value of religion that teaches accountability, professionalism, transparency, honesty, equality, integrity and loyalty against the law and leaders is still less of attention. Actually, the values cannot be ruled out and it becomes as one of the most fundamental things that are being taught by religion and it obligated for every believer. It is ordained by Allah the God Almighty about the understanding of Islam as explained in surah Al-Baqarah verse 208, which means: "o you who believe! Enter perfectly in Islam (by obeying the all the rules and regulations of Islamic religion) and follow not the footsteps of 
Shaitan. Verily he is a plain enemy to you".

The dimension of religiosity beliefs is not only focused on aqidah and syari practice but also another dimension such as dimensions of the practice (morals), dimensions of knowledge (science) and dimensions of religious experience (charity) as delivered by Suroso and Ancok (2005). Then a case about belief is not only occurred between individual to his creator, it is more than a lesson about faith in dealing with heart (tashdiq bil qalbi), faith in dealing with words (iqrar bil lisan) and also the faith in creating a good interaction (amal bin arkan) to human being. The same thing also delivered by Jalalludin (see a review of the literature) as he explained there are eight religious functions and it cannot be ruled out in practicing in daily routine.

\section{Tolerant of law}

One of the great problems in life is a mistake in understanding something. Misunderstandings in interpreting a thing will design and shape a mindset towards a value. Definition of hablumminannas from the inappropriate way and beyond the regulation has brought a misleading thought within society in general. Hablumminannas realized as a way and form to do goods among people has been interpreted in wrong way by discharging its context, circumstances, and conditions. Hence it has created a space to do corruption in a small or big scale as it growing normally and being considered as a reasonable thing.

A blurry circumstance keeps creating a gap and becoming a tool of justification against corruption behavior. The way society in respecting the guest whom an official of government through serving the best banquets is considered as something that should be done although authors have pulled a further explanation showing there is a correlation between a banquet toward the received help. In fact, the value should be contradicted to utilitarian basics which stated the impact is bigger than its benefit.

Basically, in this case, the author is comparing country' positive act toward ethical values embedded by the concept of thinking and behaving inside society. This discovery telling that the essence of the positive action is not truly embedded in society' daily routine whereas ethical values tend to affect the way of thinking and acting between the society. Therefore the embedded value has disregarded the positive act of a nation. In other words, there is a small assumption in the process of interviewing where they recapitulated most of the people in Bangka Belitung Island are tolerant to the positive and religious activities since the ethical values embedded inside the concept of thinking.

\section{Closing}

A society living in Province of Bangka Belitung Island is generally revealing themselves is very/quite piety enough stated by 162 respondent from 200 respondent $(81 \%)$. The rest of 38 respondent (19\%) declaring themselves is less/not piety and not answering/not know. Therefore the average of the religious level is quite high. From 162 respondent who stated themselves as very/quite piety, the author found a result showing 33 persons declared themselves is always/very often considering religious value in formulating decisions and 72 respondent declaring quite often. It means 105 respondents (63.3\%) is considering religion in 
determining certain thing inside someone' life.

Furthermore, from 105 respondents showed the majority of 64 respondents (60.9\%) claiming the giving outside procedure and requirements to streamline a process or the gift as a form of gratitude in dealing with governmental agencies is unreasonable. This is showing the of a religious factor has a big influence in minimizing the level of chained corruption (gratuities, collusion, and nepotism) inside society. Otherwise, the result also shows that 33 respondents $(31,4 \%)$ stated the practices as a natural thing to do. Under that fact, authors concluded that the general assumption inside society is quite high where an attitude and behavior like giving money/gift to governmental apparatus is normal and reasonable.

The last processed data stated that the majority of society arguing collusion and nepotism as a negative act with 45 respondent judge it as unethical (42.8\%) and 11 respondents judge it as a crime and criminality form (10.4\%). Hence, the total of society who sees collusion and nepotism as a form of reprehensible deeds as explained by 56 respondents (53.2\%). One thing needs to be understood and noted that 7 respondents $(6.6 \%)$ rate collusion and nepotism as a necessary and reasonable action to do in accelerating some process and 37 respondents (35.2\%) rates collusion and nepotism as a normal and reasonable thing. In other words, there are 44 respondents $(41.8 \%)$ who see collusion and nepotism as a permitted and reasonable thing to be done every day.

Basically, religion ought to control the subject of corruption behavior has not implemented properly caused by the dichotomy of mind that too dogmatic. The society of Bangka Belitung still can't run the attitudes and behavior taught by religion fully. This issue is affected by several things like ethics and culture of the society, worship only is seen as ritualistic form and society who still tolerant towards the law.

So the question is "does corruption become a culture?". Culture is a thing that makes special for certain regions and groups of people. Basically, the ethical value is implanted inside human souls as it formed in an area. Thus culture becoming an added value and special identity of a society that needs to be conserved and maintained inappropriate way. However, the local wisdom that existed among society can be changed into local crime in certain time due to the barrier and problem that grows. It also becomes a credit point in this analysis. Local wisdom as a way to create a good relation and serving guest can backfire the development and improvement of the governmental system of Indonesia in general and particularly the Province of Bangka Belitung Island.

It is very unfair to say the final conclusion consisted of a local wisdom can damage the governmental system without providing any solution and recommendation. Through hierarchical basis, the ethical value is viewed as the highest position in directing corruption behavior and it is followed by religious value and positive law. The best way to address this problem is exalting the religious value and positive law by not shrinking the ethical values. Since the ethical value decreased, it becomes a tight resistance carried out by society. Thus, people will receive a comparison in determining the attitude and behavior against corruption act. Therefore, society will be able in differentiating and placing which one is the best value without being perforce in certain condition and situation. 


\section{Macrothink}

Journal of Public Administration and Governance

ISSN 2161-7104

2018, Vol. 8, No. 2

Socialization towards the value of positive law in a state is something which is very urgent and needs to be done by the government to people particularly to the act of corruption behavior. This caused by the quantity and quality of society especially concerning the knowledge of corruption is still low so it creates a blurry solution about an issue of law which in Islam known by haqqa-haqqa batilla-batilla. Furthermore, the da'wah (propaganda) offered by religious leaders should be able to touch the social values inside society. The expected $d a$ 'wah is not always meant to be a vertical relationship between a servant toward his lord but it also capable of explaining the muamalah relationship within the ummah (and against people from different beliefs).

\section{References}

Azra, A. (2000). Pendidikan Islam Tradisi dan Modernisasi Menuju Milenium Baru. Jakarta: Lagos Wacana Ilmu.

Bertens, K. (1993). Etika. Jakarta: PT. Gramedia Pustaka Utama.

Creswell, J. C. (2009). Research Design (Third Edition): Qualitative, Quantitative, and Mixed Method Approaches. USA: Sage Publication.

Ghaniy, N., \& Hastiadi, F. F. (2017). Political, Social and Economic Determinants of Corruption. International Journal of Economic and Financial Issues, 7(4), 12-22.

Greener, S. (2008). Business Research Methods. London: Ventus Publishing ApS.

Jalaluddin. (2004). Psikologi Agama. Jakarta: Raja Grafindo Persada.

Kalangie, N. S. (1994). Kebudayaan dan Kesehatan: Pengembangan Pelayanan Kesehatan Primer melalui Pendekatan Sosiobudaya. Jakarta: Megapoin.

Levin, R., \& Rubin, D. (1998). Statistics for Management 7th Edition. New York: Prentice Hall. Inc.

Levlock, C., \& Wirtz, J. (2004). Service Marketing (People, Technology, Strategy) 5th Edition. New York: Prentice Hall. Inc.

Nasution, H. (1986). Akal dan Wahyu dalam Islam. Depok: Universitas Indonesia Press.

Newmann, L. (2006). Social Research Methods: Qualitative and Quantitative Approach. USA: Pearson International Edition.

Pope, J. (2003). Strategi Memberantas Korupsi: elemen Sistem Integritas Nasional. Jakarta: Yayasan Obor Indonesia.

Prodjohamidjojo, M. (2001). Penerapan Pembuktian Terbalik dalam Delik Korupsi. Jakarta: Pradnyaparamita.

Rousydiy, L. (1986). Puasa Hukum dan Hikmahnya berdasarkan Kitab Allah dan Sunnah Rasulullah SAW. Medan: Rainbow.

Santos, S. (2000). Buku Latihan SPSS Statistik Parametrik. Jakarta: PT. Elex Media 
Komputindo.

Santoso, A. (2009). Hoegeng: Oase Menyejukkan di Tengah Perilaku Koruptif Para Pemimpin Bangsa. Yogyakarta: Bentang Pustaka.

Seldadyo, H., \& Haan, J. d. (2006). The Determinants of Corruption: A Literature Survey and New Evidence. Turku: Finland.

Shabbir, G., \& M, A. (2007). Determinants of Corruption in Developing Countries. Pakistan: The Pakistan Development Review.

Shadabi, L. (2013). The Impact of Religion on Corruption. Journal of Business Inquiry Research, 33-42.

Subiyanto, I. (1999). Metodologi Penelitian (Manajemen dan Akuntansi). Yogyakarta: Akademi Manajemen Perusahaan.

Taylor, C. (1989). Sources of the Self: Making of The Modern Identity. USA: Harvard University Press.

Tenner, A. R., \& Toro, I. J. (1989). Total Quality Management: Three Steps to Continuous Improvement. Massachusetts: Addison Wesley Publishing Company.

Toennies, F. (1887). Community and Society: Gemeinschaft and Gesselschaft. Translated and Edited by Charles P. Loomis. Michigan: The Michigan State University Press.

Umar, H. (2002). Metode Riset Bisnis. Jakarta: PT. Gramedia.

Uyun, Q. (1998). Religiusitas dan Motif Berprestasi Mahasiswa dalam Psikologika. Yogyakarta: Universitas Islam Indonesia Press.

\section{Copyright Disclaimer}

Copyright for this article is retained by the author(s), with first publication rights granted to the journal.

This is an open-access article distributed under the terms and conditions of the Creative Commons Attribution license (http://creativecommons.org/licenses/by/4.0/). 